\title{
Tropomyosin Alpha-3 Chain
}

National Cancer Institute

\section{Source}

National Cancer Institute. Tropomyosin Alpha-3 Chain. NCI Thesaurus. Code C97851.

Tropomyosin alpha-3 chain (284 aa, $233 \mathrm{kDa}$ ) is encoded by the human TPM3 gene. This protein plays a role in the modulation of muscle contraction. 